\title{
Kajian Penggunaan Potongan Ban Bekas Terhadap Kuat Tekan Beton
}

\author{
Andreas Setiabudi ${ }^{1}$, Julio Riov ${ }^{1}$, Feisal Adri Winansa ${ }^{1}$, \\ Rio Yohannes ${ }^{1}$, Agustinus Agus Setiawan ${ }^{2}$ \\ ${ }^{1}$ Program Studi Teknik Sipil, Universitas Pembangunan Jaya \\ ${ }^{2}$ Center for Urban Studies, Universitas Pembangunan Jaya \\ agustinus@upj.ac.id
}

\begin{abstract}
Concrete is a material that is widely used in a building construction. Concrete has several properties including easy to cast and has a high compressive strength. Concrete mixed with scrap used tires is expected to reduce the density of concrete and increase the compressive strength and tensile of the concrete. Waste of used tire material is very easy to find, but this material is difficult to decompose naturally. This study aims to find the amount of concrete compressive strength by adding scrap of used tires as a partial substitution of coarse aggregates on concrete. Test specimens are cylinders with a diameter of $15 \mathrm{~cm}$ and a height of $30 \mathrm{~cm}$ with variations in the addition of tires by $5 \%, 10 \%$, and $15 \%$ of the volume of coarse aggregate. The target of concrete quality is $K-250\left(f^{\prime} c=20.75 \mathrm{MPa}\right)$ at the age of 28 days. The test results for $5 \%$ of tires produced $138.71 \mathrm{~kg} / \mathrm{cm}^{2}$, for $10 \%$ the tires produced $108.25 \mathrm{~kg} / \mathrm{cm}^{2}$, and for $15 \%$ the tires produced $84.37 \mathrm{~kg} / \mathrm{cm}^{2}$. The decrease in the weight of the concrete which is for the $5 \%$ mixture is $4.33 \%$ of the normal weight, for $10 \%$ at $6.51 \%$ of the normal weight and for $15 \%$ the weight of the concrete decreases by 5,44\% from the normal weight.
\end{abstract}

Keywords : concrete, tensile strength, compressive strength, scrap used tires

\begin{abstract}
Abstrak : Beton adalah material yang banyak digunakan dalam suatu konstruksi bangunan. Beton memiliki beberapa sifat antara lain mudah untuk dicetak serta memiliki kuat tekan yang tinggi. Beton yang dicampur dengan potongan ban bekas diharapkan mampu mengurangi berat jenis beton serta menambah kuat tekan dan tarik beton. Limbah bahan ban bekas sangatlah mudah ditemukan, namun bahan ini susah terurai secara alami. Penelitian ini bertujuan untuk mencari besarnya kuat tekan beton dengan penambahan potongan ban bekas sebagai pengganti sebagian dari agregat kasar pada beton. Benda uji berupa silinder berdiameter $15 \mathrm{~cm}$ dan tinggi $30 \mathrm{~cm}$ dengan variasi penambahan ban sebesar 5\%,10\%, dan $15 \%$ dari volume agregat kasar. Mutu beton rencana yaitu K-250 $\left(f{ }^{\prime}{ }_{\mathrm{c}}=20,75 \mathrm{MPa}\right)$ pada umur 28 hari. Hasil pengujian untuk $5 \%$ ban menghasilkan $138,71 \mathrm{~kg} / \mathrm{cm}^{2}$, untuk $10 \%$ ban menghasilkan $108,25 \mathrm{~kg} / \mathrm{cm}^{2}$, dan untuk $15 \%$ ban menghasilkan $84,37 \mathrm{~kg} / \mathrm{cm}^{2}$. Penurunan berat beton yaitu untuk campuran $5 \%$ adalah $4,33 \%$ dari berat normal, untuk $10 \%$ sebesar $6,51 \%$ dari berat normal dan untuk $15 \%$ berat beton turun sebesar $5,44 \%$ dari berat normal.
\end{abstract}

Kata Kunci : beton, kuat tarik, kuat tekan, potongan ban bekas

\section{PENDAHULUAN}

Limbah ban bekas merupakan salah satu penyumbang limbah terbanyak. Hal ini dapat dipahami seiring dengan makin banyaknya jumlah kendaraan setiap tahunnya. Dengan banyaknya jumlah kendaraan bermotor yang ada saat ini tentu akan menghasilkan limbah ban yang besar pula. Ban yang tidak dapat digunakan kembali biasanya adalah ban yang alurnya sudah habis atau tipis.

Beberapa cara mengelola limbah ban ini diantara lain dibakar (vulkanisir) atau di daur ulang menjadi serbuk karet. Adapun keuntungan menggunakan serbuk karet dari ban bekas karena harga karet mentah tidak tetap. Disaat harga naik pihak harga produksi juga akan ikut terkerek naik oleh karena itu ban bekas digunakan dilihat dari bahan-bahan penyusun utama ban tahan terhadap air, memiliki kestabilan yang cukup, ketahanan yang tinggi, dan memiliki tingkat fleksibilitas dan sifat lentur yang cukup baik serta karet memiliki sifat menyerap getaran.

Selain itu upaya baru pemanfaatan limbah ban bekas adalah dengan menambahkannya ke dalam campuran beton. Ban bekas yang telah tak terpakai 
dipotong-potong menjadi potongan kecil untuk kemudian dicampur ke dalam campuran beton sebagai pengganti sebagian agregat kasar. Penggunaan potongan limbah ban karet dalam campuran beton ini diharapkan dapat menghasilkan beton yang memiliki kuat tekan dan tarik melebihi beton normal.

\section{Batasan Masalah}

- Menggunakan potongan ban dengan ukuran $(1 \times 1 \times 2 \mathrm{~cm})$ dengan variasi penambahan potongan ban sebesar $5 \%, 10 \%$ dan $15 \%$ dari volume agregat kasar.

- Menggunakan beton dengan target mutu K-250 atau $f^{\prime}{ }_{\mathrm{c}} 20,75 \mathrm{MPa}$.

- Semen yang digunakan yaitu semen portland tipe 1 merek Semen Padang.

- Pasir yang digunakan adalah pasir rangkas dengan ukuran $<5 \mathrm{~mm}$.

- Agregat kasar yang digunakan adalah agregat yang berasal dari daerah Parung dengan ukuran $<40 \mathrm{~mm}$.

- Air yang digunakan adalah air PDAM.

\section{Tujuan Penelitian}

- Untuk mengetahui pengaruh penggantian sebagian agregat kasar menggunakan potongan ban bekas terhadap kuat tekan beton.

- Untuk mengetahui efek pengantian sebagian agregat terhadap berat volume beton.

\section{KAJIAN PUSTAKA \\ Beton}

Menurut KBBI (Kamus Besar Bahasa Indonesia) beton merupakan campuran semen, kerikil, dan pasir yang diaduk dengan air untuk tiang rumah, pilar, dinding, dan sebagainya. Beton sendiri memiliki beberapa sifat beton antara lain : kompaktibilitas, mobilitas, workabilitas, stabilitas.

\section{Semen}

Semen yang digunakan dalam bahan beton adalah semen jenis portland, karena semen jenis ini merupakan bahan pengikat yang berfungsi untuk mengikat agregat halus dan agregat kasar dengan air dalam suatu adukan. Semen Portland yang berkualitas harus memenuhi syarat berikut :

Semen tidak kadaluarsa, semen pun seperti makanan instant dapat juga kadaluarsa. Semen yang kadaluarsa dapat diperiksa dengan cara dipegang oleh tangan, bila masih hangat, maka semen belum kadaluwarsa.

Semen belum mulai menggumpal. Semen yang sudah ditimbun terlalu lama maka akan menjadi bergumpal, semen yang baik adalah semen yang ditimbun tidak lebih dari 1 bulan dengan sistem penyimpanan menggunakan alas dan tidak boleh lebih dari 10 tumpukan semen.

Semen masih bereaksi, semen yang baik yaitu semen yang belum mulai menggumpal dan apabila digenggam dengan tangan maka akan jatuh berhamburan.

\section{Agregat}

Pada dasarnya orang akan menggunakan kerikil sebagai bahan pencampur (Agregat). Sifat yang paling penting dari suatu agregat adalah kekuatan hancur dan ketahanan terhadap benturan. Dua hal ini dapat mempengaruhi ikatan dengan pasta semen, porositas, serta keretakan beton. Agregat dapat dikelompokan menjadi 2 tipe, yaitu agregat halus dan agregat kasar. Agregat (bahan pengisi) didalam adukan beton menempati $70 \%$ dari volume beton. Oleh karena itu, agregat akan mempengaruhi sifat sifat beton.

Air

Air diperlukan pembuatan beton untuk memicu proses kimiawi semen sebagai perekat, membasahi agregat dan memberikan kemudahan dalam pekerjaan beton. dibutuhkan air dengan kualitas yang baik karena kualitas air akan mempengaruhi pengerasan dan keawetan dari beton. Syarat air yang berkualitas untuk pembuatan beton :

a. Air tidak mengandung bahan organik, misalnya sisa tumbuhan. 
b. Air tidak boleh mengandung bahan kimia, misalnya besi, sulfat dan klorida, karena zat-zat kimia ini dapat merusak mutu beton.

c. Air tidak mengandung minyak, karena minyak akan menghambat hidrasi yang diperlukan oleh beton untuk ikatan awal.

d. Tidak mengandung garam.

\section{Ban}

Berdasarkan bahan-bahan penyusun utamanya yaitu karet alam dan karet sintetis, dimana karet memiliki sifat tahan terhadap cuaca, tahan terhadap air, memiliki kestabilan yang cukup, ketahanan yang tinggi, dan memiliki tingkat fleksibilitas dan sifat lentur yang cukup baik serta karet memiliki sifat menyerap getaran.

\section{METODOLOGI PENELITIAN}

Metode penelitian dilakukan secara eksperimental dengan melakukan serangkaian pengujian di laboratorium. Metodologi penelitian ini dijelaskan dalam bagan alir pada Gambar 1.

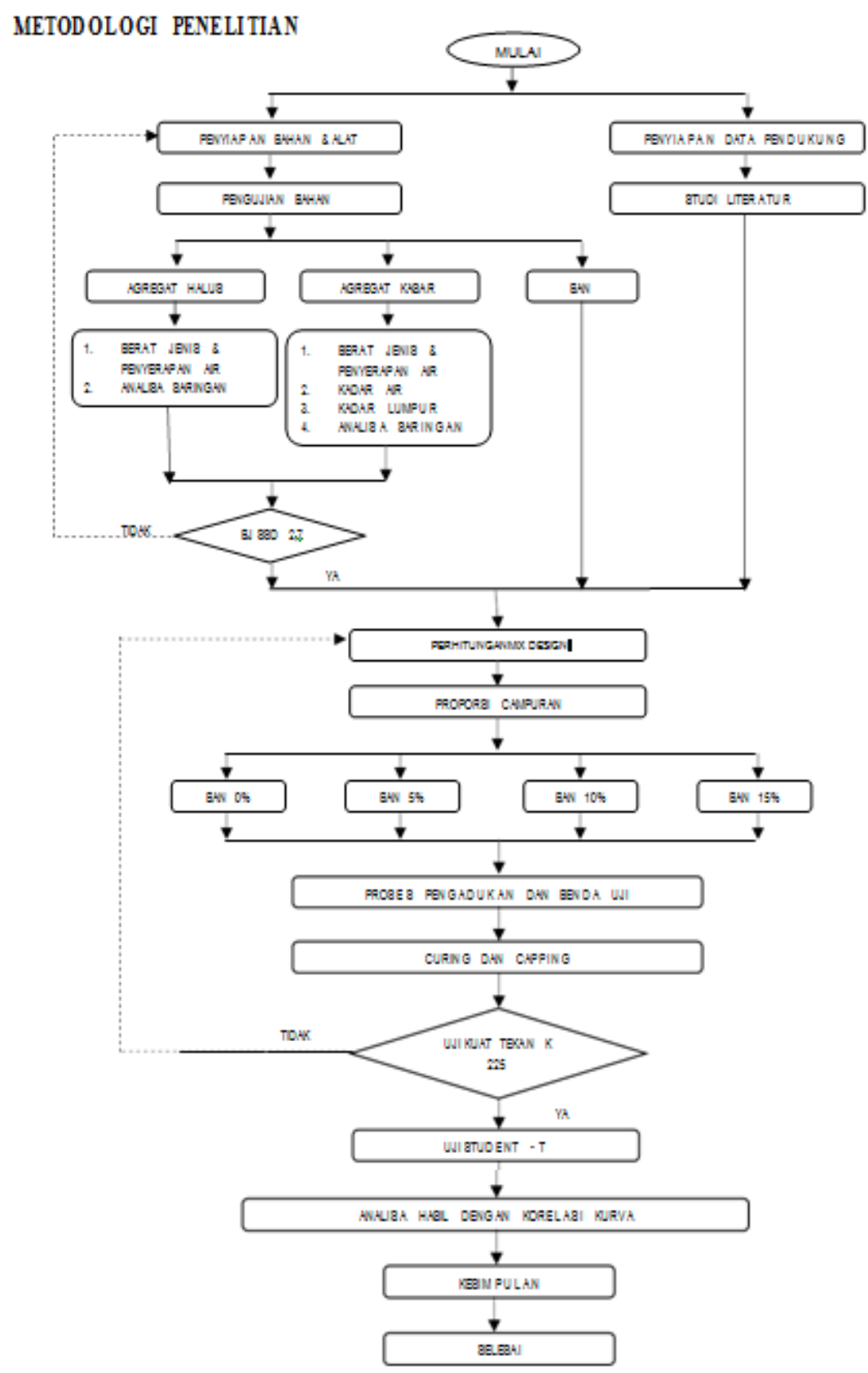

Gambar 1. Metodologi Penelitian 


\section{HASIL PENELITIAN DAN ANALISIS}

Pengujian beton dilakukan setelah beton mencapai umur 28 hari. Sedangkan kuat tekan yang direncanakan $\left(f^{\prime}{ }_{c}\right)$ sebesar 20,75 MPa atau K-250 (beton normal).

Berat jenis beton normal, tanpa tambahan potongan ban bekas diperoleh sebesar $2.265,7 \mathrm{~kg} / \mathrm{m}^{3}$. Penambahan $5 \%$ potongan ban bekas diperoleh berat jenis sebesar 2.167,39 $\mathrm{kg} / \mathrm{m}^{3}$. Untuk penambahan konsentrasi potongan ban bekas sebesar $10 \%$ mendapatkan berat jenis $2118,14 \mathrm{~kg} / \mathrm{m}^{3}$. Dan penambahan volume potongan ban bekas sebesar $15 \%$ mendapatkan berat volume 2.142,42 $\mathrm{kg} / \mathrm{m}^{3}$, turun sebesar $5,44 \%$. Dari data ini dapat dilihat semakin banyak penambahan potongan ban bekas sebagai pengganti agregat kasar dalam campuran beton akan dapat menurunkan berat jenis beton.

Tabel 1. Berat Jenis dan Kuat Tekan Beton

\begin{tabular}{ccc}
\hline $\begin{array}{c}\% \\
\text { Potongan } \\
\text { Ban }\end{array}$ & $\begin{array}{c}\text { Berat Jenis } \\
\left(\mathbf{k g} / \mathbf{m}^{\mathbf{3}}\right)\end{array}$ & $\begin{array}{c}\text { Kuat } \\
\text { Tekan } \\
\left(\mathbf{k g f} / \mathbf{c m}^{\mathbf{2}}\right)\end{array}$ \\
\hline $\mathbf{0}$ & $2.265,70$ & 210,06 \\
\hline $\mathbf{5}$ & $2.167,39$ & 138,71 \\
\hline $\mathbf{1 0}$ & $2.118,14$ & 108,25 \\
\hline $\mathbf{5}$ & $2.142,42$ & 84,37 \\
\hline
\end{tabular}

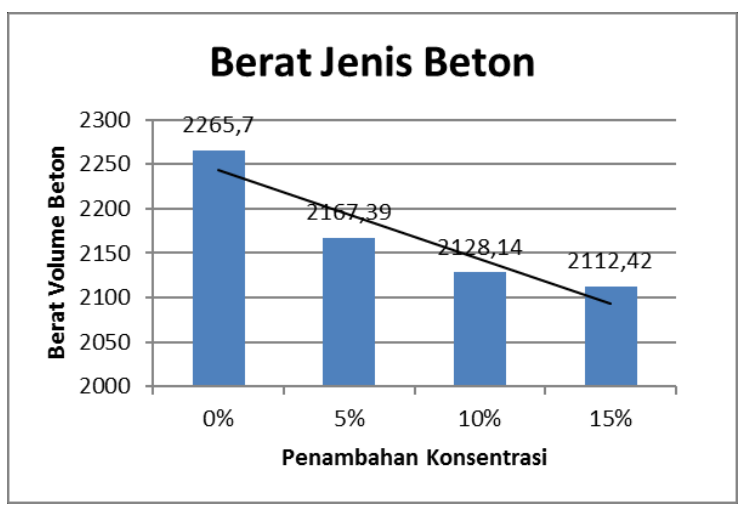

Gambar 2. Berat Jenis Beton

Untuk beton normal tanpa penambahan, mendapatkan kuat tekan sebesar 210,06 $\mathrm{kgf} / \mathrm{cm}^{2}$. Untuk penambahan sebesar $5 \%$ akan mereduksi kuat tekan menjadi $138,71 \mathrm{kgf} / \mathrm{cm}^{2}$. Penambahan konsentrasi potongan sebesar $10 \%$ mereduksi kuat tekan $108,25 \mathrm{kgf} / \mathrm{cm}^{2}$.
Sedangkan penambahan $15 \%$ potongan ban akan menghasilkan kuat tekan sebesar $84,37 \mathrm{kgf} / \mathrm{cm}^{2}$, turun $59,83 \%$. Dari hasil ini terlihat bahwa makin besar penambahan potongan ban bekas ke dalam campuran beton akan menurunkan kuat tekan dari beton.

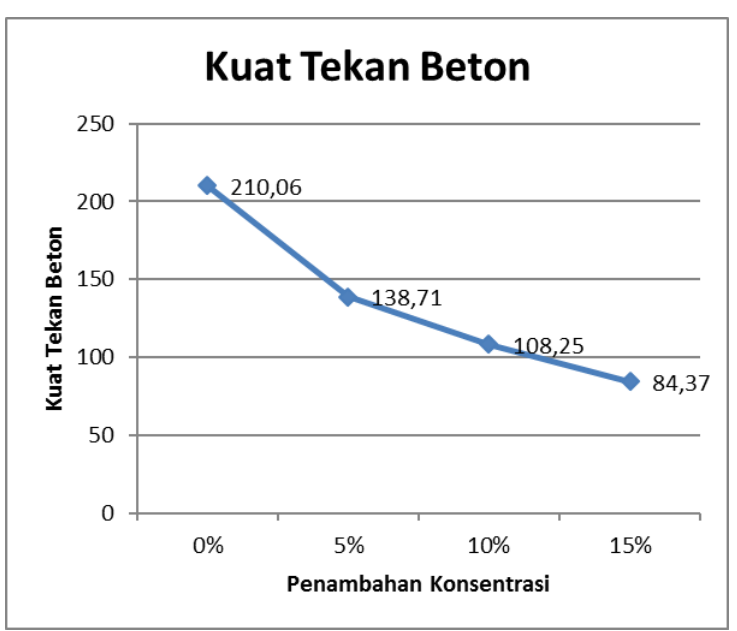

Gambar 3. Kuat Tekan Beton

\section{KESIMPULAN}

1. Penambahan potongan ban pada beton tidak menambahkan kuat tekan pada beton bahkan menurun kuat tekan beton. Pada penambahan potongan ban hingga $15 \%$ akan menurunkan kuat tekan hingga $59,83 \%$.

2. Campuran beton dengan penambahan ban bekas hingga $15 \%$ akan mengurangi berat beton normal hingga $5,44 \%$

3. Ban yang dicampur pada agregat kasar pada beton tidak dapat digunakan sebagai beton yang digunakan untuk pekerjaan struktural, karena kuat tekan yang terlalu rendah dibanding beton dengan campuran biasanya.

4. Campuran Beton dengan penambahan material ban bekas, kurang cocok untuk menaikkan mutu beton, sehingga perlu diteliti lebih lanjut lagi untuk campuran ini, kemungkinan alternatif lainnya untuk penggunaan ban pada campurran beton misalnya untuk perkerasan Jalan Raya (rigid pavement). 


\section{DAFTAR PUSTAKA}

1. Anonim, SKSNI T-15-1990-01-03 Bandung, Yayasan LPBM Bandung, 1990.

2. Djedjen, A., 2008. Jobsheet Pengujian Bahan II, Depok : Politeknik Negeri Jakarta, 2008.

3. Lativa, E.Z., Teknologi Bahan II, Depok, Jurusan Teknik Sipil, Politeknik Negeri Jakarta, 2003.

4. Susilowati, A., Jobsheet Laboratorium Uji Bahan, 2003. 